\title{
WOOD AND BARK FIBER CHARACTERISTICS OF Acacia melanoxylon AND COMPARISON TO Eucalyptus globules
}

\author{
Fatima Tavares ${ }^{1}$, Teresa Quilhó2 ${ }^{2}$ Helena Pereira ${ }^{3}$
}

(received: January 28, 2010; accepted: November 30, 2010)

\begin{abstract}
Wood and bark fibers of Acacia melanoxylon were characterized and compared to Eucalyptus globulus which is a major quality source of pulp fibers. In 20 trees from four sites, fiber length and wall thickness were measured at 5,35 and $65 \%$ of total tree height and at 10,30,50, 70 and $90 \%$ of the distance from pith. Maceration were prepared in a 1:1 glacial acetic acid:hydrogen peroxide solution. Wood and bark fiber length varied between $0.90-0.96 \mathrm{~mm}$ and $1.33-1.59 \mathrm{~mm}$ respectively. The cell wall thickness varied between $3.45-3.89 \mu \mathrm{m}$ in wood and $5.01-5.40 \mu \mathrm{m}$ in bark. Wood and bark fiber length decreased from the bottom to the top of the tree and cell wall thickness had no specific pattern for axial variation. Fiber length and wall thickness increased from the pith to the bark, but the wall thickness increased slightly with some fluctuations. In Acacia melanoxylon significant site differences were found in relation to bark fiber length and to wood wall thickness. The fibers of Acacia melanoxylon were similar to those of Eucalyptus globulus but the wood fibers were thinner and the bark fibers thicker. The radial variation was similar in both species. In wood of Eucalyptus globulus, fiber wall thickness increases from the base to the middle of tree height and decreases to the top; in the bark decreases from the base to the top. In Eucalyptus globulus fibers bark are higher in the top.
\end{abstract}

Key words: Xylem, phloem, cell biometry, acacia, eucalypts.

\section{COMPARAÇÃO DAS CARACTERÍSTICAS DAS FIBRAS DA MADEIRA E DA CASCA DA Acacia melanoxylon COM AS DO Eucalyptus globulus}

\begin{abstract}
RESUMO: Caracterizaram-se as fibras da madeira e casca da Acacia melanoxylon e compararam-se com as do Eucalyptus globulus, principal espécie usada em Portugal para celulose. Abateram-se vinte árvores da Acacia melanoxylon em quatro locais. Determinou-se o comprimento e a espessura de parede das fibras em elementos dissociados com o soluto de Franklin. A variação radial foi estudada a 10, 30, 50, 70 e 90\% do comprimento do raio e a variação axial a 5, 35 e 65\% da altura da árvore. Na Acacia melanoxylon, o comprimento das fibras da madeira e casca oscilou entre 0,90-0,96 $\mathrm{mm}$ e 1,33-1,59 $\mathrm{mm}$ respectivamente e a espessura da parede

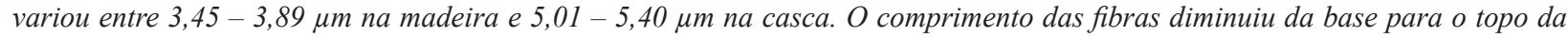
árvore. O comprimento e a espessura de parede aumentaram radialmente, embora a espessura com algumas flutuações. Axialmente a espessura da parede não mostrou um padrão especifico de variação. Na Acacia melanoxylon o comprimento das fibras da casca e a espessura da parede das fibras da madeira apresentaram diferenças significativas entre locais. As fibras são semelhantes às do Eucalyptus globulus, embora mais finas na madeira e mais espessas na casca. O padrão de variação radial é semelhante nas duas espécies. No Eucalyptus globulus, a espessura da parede das fibras da madeira aumenta até meio da altura da árvore e depois diminui para o topo; na casca diminui da base para o topo. No Eucalyptus globulus as fibras da casca são maiores no topo.
\end{abstract}

Palavras-chave: Xilema, floema, biometria celular, acácia, eucalipto.

\section{INTRODUCTION}

Acacia melanoxylon R. Br. and Eucalyptus globulus L. are tree species native to Australia that occur naturally across a wide range of forest ecosystems. They were introduced in Portugal as ornamentals in the late XIXth century and their expansion occurred through national forestation programs.

In Europe, Acacia melanoxylon is considered as invasive, characterized by vigorous tree or root sprouts and with seed germination stimulated by fire. Eucalyptus globulus, as most eucalypt species, also releases the seed and is capable of vegetative regeneration after fire. In Portugal, Acacia melanoxylon is found associated with pines along the Atlantic Coast and in pure or mixed stands with other hardwoods and pines in the inner part of the country, especially in fire risk areas.

Acacia species were primarily cultivated for bark, which was used in the tanning industry (ILVESSALOPFAFFLI, 1995) but they are important for several

\footnotetext{
${ }^{1}$ Engenheira Florestal, Professora Doutora em Engenharia Florestal - Centro de Estudos Florestais - Instututo Superior de Agronomia - Universidade Técnica de Lisboa - Tapada da Ajuda - 1349-017 - Lisboa, Portugal - mftavares@isa.utl.pt

${ }^{2}$ Bióloga, Pesquisadora Doutora em Engenharia Florestal - Centro das Florestas e Produtos Florestais - Instituto de Investigação Científica Tropical - Tapada da Ajuda - 1349-017 - Lisboa, Portugal - terisantos@isa.utl.pt

${ }^{3}$ Engenheira Química, Professora Doutora em Engenharia Florestal - Centro de Estudos Florestais - Instituto Superior de Agronomia - Universidade Técnica de Lisboa - Tapada da Ajuda - 1349-017 - Lisboa, Portugal - HelenaPereira@reitoria.utl.pt
} 
purposes including building and furniture, fuelwood, perfume, traditional medicine, pulp and paper and in general have a good biomass potential (HARRIS, 2004). They are used also for wood-based composite and panel products (PEDIEU et al., 2009). The wood of Acacia melanoxylon is highly regarded in its natural region as a quality timber for carpentry and cabinet making (JENNINGS et al., 2003) and with potential to develop into a quality leader of short-fiber pulp (GIL et al., 1999).

Very little has been published on the wood and bark anatomy of Acacia melanoxylon and on its variability (GHOUSE; IQBAL, 1977; IQBAL; GHOUSE, 1983; QUINTANAR ISAIAS et al., 2005; SAHRI et al., 1993). In this context, the biometric characteristics of fibers are especially important given their relevance to properties and end-uses.

The aim of the this study is to characterize the wood and bark structure of Acacia melanoxylon in relation to fiber biometry (length and wall thickness) and their variation within and between trees growing in different site conditions in Portugal, in a context of raw-material quality evaluation for pulping. Therefore the results are compared with the fiber characteristics of Eucalyptus globulus, which is a major source for production of quality short fiber pulp.

\section{MATERIAL AND METHODS}

The study was made on 20 trees (five trees in each site), with a $40 \mathrm{~cm}$ DBH class sampled in four stands located in northern and central Portugal: Caminha, Ponte de Lima, Ovar, Viseu. The location and characterization of the sites are summarised in Table 1.

The trees were bucked and stem discs with $5 \mathrm{~cm}$ thickness were taken at different height levels. The axial variation of fiber length and cell wall thickness was studied in stem discs taken at $5 \%, 35 \%$ and $65 \%$ of total tree height, both in wood and bark. The radial variation of wood fiber length and cell wall thickness in each height level was measured in five radial positions at 10, 30, 50, 70 and $90 \%$ of the distance from pith.

Fiber length and cell wall thickness were measured in bark and wood samples macerated in a 1:1 glacial acetic acid:hydrogen peroxide solution. Two slides and 20 fibers per slide were measured for each sampling point. Preliminary testing showed that with this sampling intensity the error was below $5 \%$ for a $95 \%$ confidence level. The fibers were measured with a Leitz ASM 68K semi-automatic image analyser.

Mean values were calculated for each height level as the arithmetic mean of all the measured radial positions. Mean values for the tree were calculated as the arithmetic mean of the three height levels studied in each tree.

Statistical analysis was made using the Sigma Stat Scientific Statistical software SigmaStat from Jandel Corporation. Analysis of variance (ANOVA) was applied to compare if the differences between wood and bark fiber length and wall thickness from different sites are statistically significant different at a 0.05 confidence level (QUILHÓ et al., 2000).

\section{RESULTS AND DISCUSSION}

Figure 1 shows the general aspect of the dissociated wood fibers of Acacia melanoxylon (Figure 1a and 1b) and of Eucalyptus globulus (Figure 1c). The wood fibers in these two species are fusiform with apical extensions at both ends. In some of the trees the wood fibers were bifurcated at one end (Figure 1b).

Bark fibers of Acacia melanoxylon are similar to bark fibers of Eucalyptus globulus as shown in Figure $2 \mathrm{a}$ and $2 \mathrm{~b}$ respectively. They are fusiform with apical extensions at both ends. Bifurcated fibers at one end can also be found in Acacia melanoxylon.

Table 1 - Location and characterization of sampling sites.

Tabela 1 - Localização e caracterização dos locais de amostragem.

\begin{tabular}{|c|c|c|c|c|}
\hline Site & Caminha & Ponte de Lima & Ovar & Viseu \\
\hline Latitude & $41^{\circ} 53^{\prime} \mathrm{N}$ & $41^{\circ} 43^{\prime} \mathrm{N}$ & $40^{\circ} 57^{\prime} \mathrm{N}$ & $40^{\circ} 41^{\prime} \mathrm{N}$ \\
\hline Longitude & $8^{\circ} 50^{\prime} \mathrm{W}$ & $8^{\circ} 50^{\prime} \mathrm{W}$ & $8^{\circ} 38^{\prime} \mathrm{W}$ & $7^{\circ} 55^{\prime} \mathrm{W}$ \\
\hline Altitude (m) & 8 & 154 & 7 & 548 \\
\hline Rainfall (mm/year) & 1304 & 1720 & 1152 & 1229 \\
\hline Mean temperature $\left({ }^{\circ} \mathrm{C}\right)$ & 14.3 & 14.0 & 13.9 & 13.0 \\
\hline Soil origin & Sand & Granite & Sand & Granite \\
\hline
\end{tabular}

Cerne, Lavras, v. 17, n. 1, p. 61-68, jan./mar. 2011 
(a)

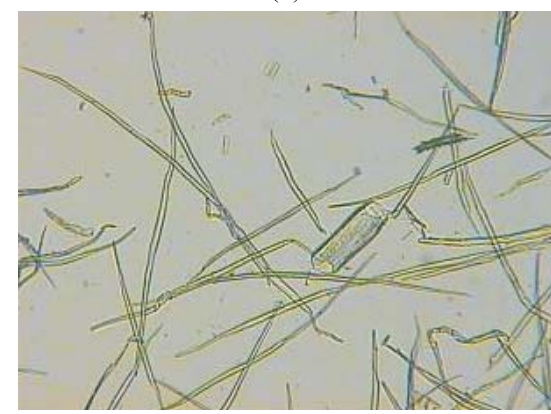

(b)

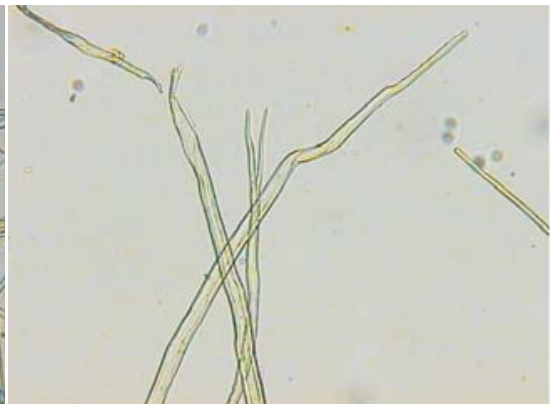

(c)

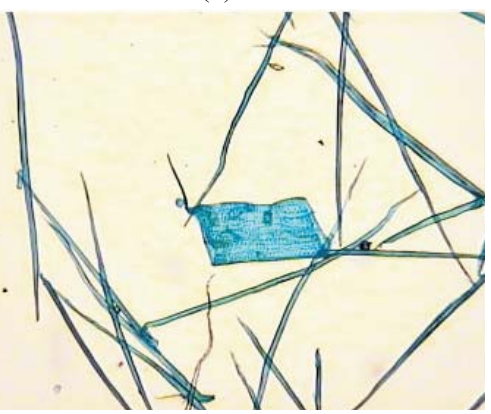

Figure 1 - Dissociated wood samples: (a) Acacia melanoxylon: libriform fibers and one vessel element; (b) Acacia melanoxylon: libriform fibers with one bifurcated fiber at one end and (c) Eucalyptus globulus: libriform fibers and one vessel element.

Figura 1 - Elementos dissociados da madeira: (a)Acacia melanoxylon: fibras liberiformes e um elemento de vaso;(b) Acacia melanoxylon: fibras liberiformes, sendo uma bifurcada numa extremidade e (c) Eucalyptus globulus: fibras liberiformes e um elemento de vaso.

(a)

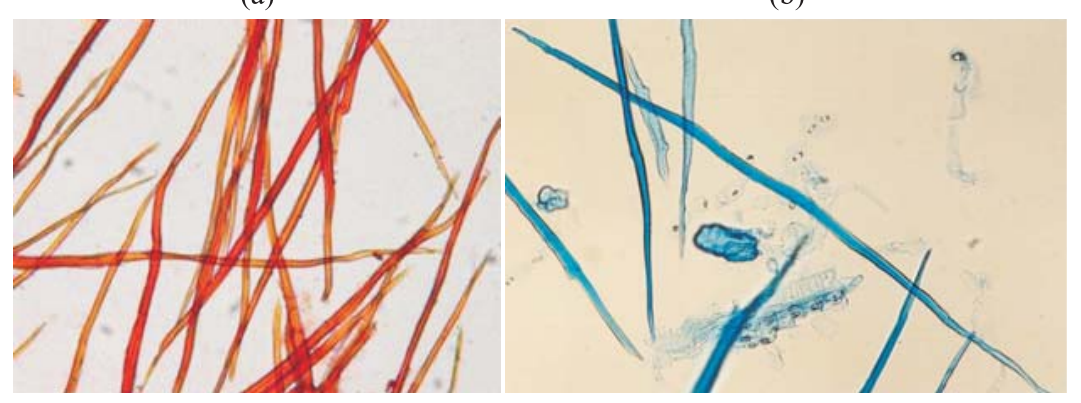

Figure 2 - Dissociated bark samples: libriform fibers; (a) Acacia melanoxylon and (b) Eucalyptus globulus.

Figura 2 - Elementos dissociados da casca: fibras liberiformes; (a) Acacia melanoxylon e (b) Eucalyptus globulus.

The fibers of Acacia melanoxylon and Eucalyptus globulus are morphologically identical in bark and wood, but longer in the bark of both species.

\subsection{Fiber length}

The fiber length of Acacia melanoxylon wood and bark ranged between 0.90-0.96 $\mathrm{mm}$ and 1.33-1.59 mm, respectively (Table 2 ).

Table 2 - Wood and bark fiber length ( $\mathrm{mm}$ ) for Acacia melanoxylon in four sites. Mean and standard deviation of five trees per site.

Tabela 2 - Comprimento das fibras da madeira e da casca ( $\mathrm{mm}$ ) da Acacia melanoxylon nos quatro locais. Média e desvio padrão de 5 árvores por local.

\begin{tabular}{lcccc}
\hline & Caminha & Ponte de Lima & Ovar & Viseu \\
\hline Wood & $0.90 \pm 0.02$ & $0.94 \pm 0.02$ & $0.96 \pm 0.06$ & $0.96 \pm 0.04$ \\
Bark & $1.33 \pm 0.04$ & $1.42 \pm 0.11$ & $1.59 \pm 0.12$ & $1.35 \pm 0.05$ \\
\hline
\end{tabular}

The results are close to those described for other Acacia species, namely Acacia mangium: mean value of $1.08 \mathrm{~mm}$ with a range of $0.96 \mathrm{~mm}$ to $1.20 \mathrm{~mm}$ (LIM; GAN, 2000; LOGAN; BALODIS, 1982), $0.80 \mathrm{~mm}$ to $1.3 \mathrm{~mm}$ (WU; WANG, 1988) and $0.9 \mathrm{~mm}$ to $1.3 \mathrm{~mm}$ (RICHTER; DALLWITZ, 2000). Kim et al. (2008) in six natural hybrid clones of Acacia mangium and Acacia auriculiformes observed values from $0.86 \mathrm{~mm}$ to $0.93 \mathrm{~mm}$.

The mean wood fiber length of Acacia melanoxylon obtained in this study is similar to values reported for Eucalyptus globulus of $1.0 \mathrm{~mm}$ (CARVALHO, 1962), $0.87 \mathrm{~mm}$ to $1.04 \mathrm{~mm}$ (JORGE et al., 2000), $0.923 \mathrm{~mm}$ (ONA et al., 2001), $0.941 \mathrm{~mm}$ to $1.192 \mathrm{~mm}$ (IGARTÚA et al., 2002) and $0.888 \mathrm{~mm}$ to $0.958 \mathrm{~mm}$ (MIRANDA; PEREIRA, 2002).

The average bark fiber length determined in Acacia melanoxylon fits into the range of $0.833-1.100 \mathrm{~mm}$ reported for this species by Ghouse and Iqbal (1977) and

Cerne, Lavras, v. 17, n. 1, p. 61-68, jan./mar. 2011 
also into other Acacia species (QUINTANAR ISAIS et al., 2005), i.e. Acacia bilimekii (1.016 -1.201 mm) or Acacia cochliacantha $(1.281-1.352 \mathrm{~mm})$, and a little higher than those reported by Iqbal and Ghouse (1983) for Acacia nilotica var. telia $(0.986-1.188 \mathrm{~mm})$.

The average bark fiber length in Acacia melanoxylon is similar to the values determined in Eucalyptus globulus bark of $1.28 \mathrm{~mm}$ (QUILHÓ, 1998) and of $1.02 \mathrm{~mm}$ and $1.04 \mathrm{~mm}$ (JORGE et al., 2000).

In Acacia melanoxylon, fiber length was in average $35 \%$ higher in bark than in wood. The same was also reported in Acacia cochliacantha ( $>30 \%$ higher) by Quintanar Isaias et al. (2005) and in various genus and species i.e. in Eucalyptus (20\% higher) by Hillis (1972) and Jorge et al. (2000). However in Acacia nilotica Iqbal and Ghouse (1983) observed similar wood and bark fiber length.

The wood fiber length of Acacia melanoxylon was similar in the four sites and no statistical significant differences were found between sites. For bark fiber length, significant site differences $(\mathrm{P}<0.005)$ were found between Ovar and the other three sites. For Eucalyptus globulus, Jorge et al. (2000) and Quilhó et al. (2000) reported that wood and bark fiber length was affected by site, while Jorge (1994) and Onofre (1999) found no statistical significant differences between sites in relation to wood fiber length.

\subsubsection{Radial variation of wood fiber length}

Figure 3 shows the radial variation of wood fiber length in Acacia melanoxylon with increasing distance from the pith. Fiber length increased from an average $0.75 \mathrm{~mm}$ near the pith, to $0.98 \mathrm{~mm}$ at mid position and to $1.06 \mathrm{~mm}$ at the periphery ( $90 \%$ of the distance from pith). Average fiber length increased more rapidly between pith and middle positions than between mid and periphery positions (by $0.23 \mathrm{~mm}$ and $0.08 \mathrm{~mm}$ respectively). At the periphery, fiber length was longer than $1.00 \mathrm{~mm}$ in all sites. Radial variation of fiber length showed the minimal mean value near the pith in Caminha $(0.69 \mathrm{~mm})$, while the maximal mean value $(1.09 \mathrm{~mm})$ was found near the bark in Viseu (Figure 3).

Fiber dimensions increased in general from pith to bark. Sahri et al. (1993), in 4- and 8-year-old trees of Acacia mangium registered the same trend of radial variation as well as Honjo et al. (2005) for ages of 2 to 14 years where the fiber length varied between $0.9 \mathrm{~mm}$ and $1.3 \mathrm{~mm}$ near the bark and between $0.4 \mathrm{~mm}$ and $0.6 \mathrm{~mm}$ near the pith. The same pattern of fiber length variation

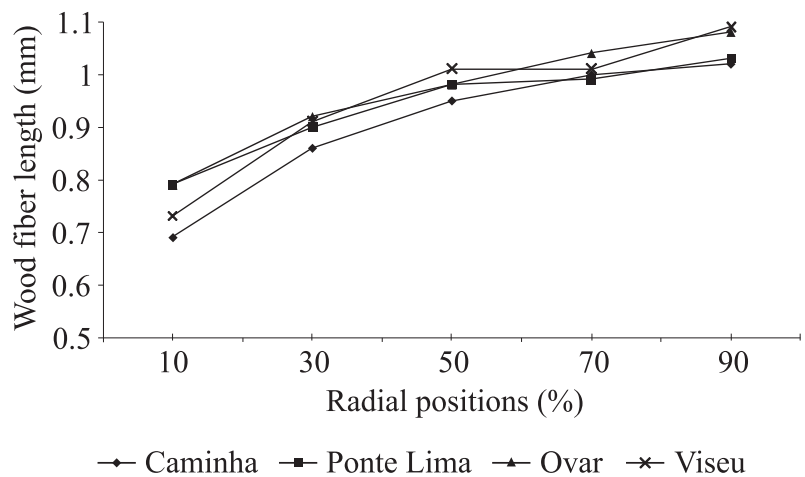

Figure 3 - Radial variation of fiber length of Acacia melanoxylon in four sites.

Figura 3 - Variação radial do comprimento das fibras da Acacia melanoxylon nos quatro locais.

was reported for Acacia bilimeki $(1.032 \mathrm{~mm}$ to 1.077 $\mathrm{mm})$ and it was different in Acacia cochiacantha with $0.780 \mathrm{~mm}$ near the pith and $0.727 \mathrm{~mm}$ close to the bark (QUINTANAR ISAIAS et al., 2005).

Eucalyptus globulus shows the same radial pattern of variation of wood fiber length with an increase from pith to bark: from $0.59 \mathrm{~mm}$ to $1.254 \mathrm{~mm}$ (TOMAZELLO FILHO, 1987), $0.69 \mathrm{~mm}$ to $1.18 \mathrm{~mm}$ (JORGE, 1994), 0.74 $\mathrm{mm}$ to $1.09 \mathrm{~mm}$ (ONOFRE, 1999), $0.63 \mathrm{~mm}$ to $1.03 \mathrm{~mm}$ (TAVARES et al., 2004). Igartúa et al. (2002) reported fibers longer than $1 \mathrm{~mm}$ in radial positions greater than $50 \%$.

\subsubsection{Axial variation of wood and bark fiber length}

Figures 4 and 5 show the axial variation of wood and bark fiber length in Acacia melanoxylon, respectively.

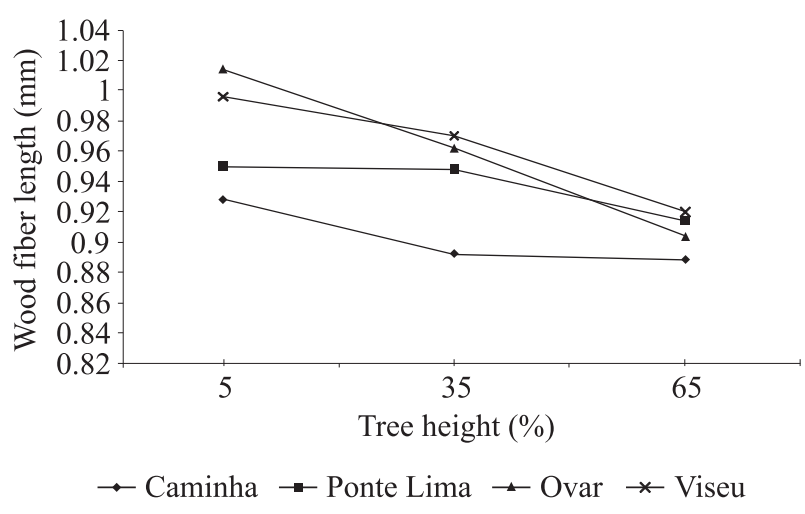

Figure 4 - Axial variation of wood fiber length of Acacia melanoxylon in four sites.

Figura 4 - Variação axial do comprimento das fibras da madeira da Acacia melanoxylon nos quatro locais. 


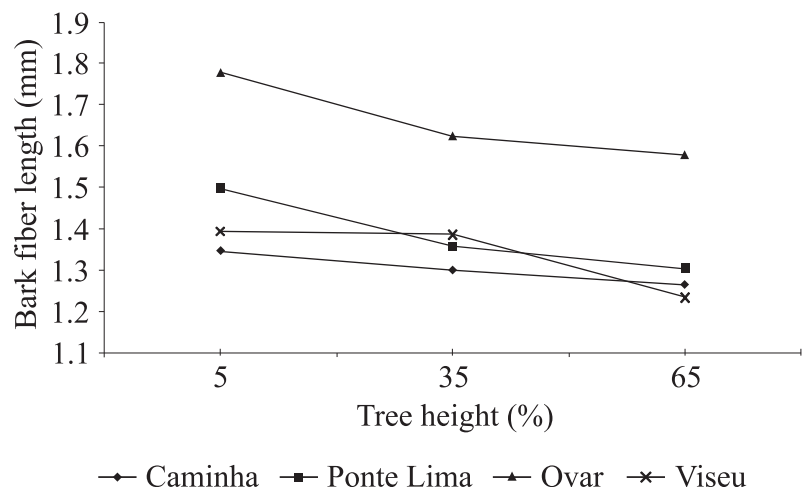

Figure 5 - Axial variation of bark fiber length of Acacia melanoxylon in four sites.

Figura 5 -Variação axial do comprimento das fibras da casca da Acacia melanoxylon nos quatro locais.

The axial variation of fiber length in wood was characterised by a slight decrease towards the top of the tree (Figure 4), from an average of $0.97 \mathrm{~mm}$ and 0.94 $\mathrm{mm}$ to $0.91 \mathrm{~mm}$ at $5 \%, 35 \%$ and $65 \%$ of total tree height respectively. The maximal mean value was determined at $5 \%$ of total tree height in Ovar $(1.01 \mathrm{~mm})$ and the minimum occurred in Caminha $(0.89 \mathrm{~mm})$ at $65 \%$ height level.

Very little has been published on axial variation patterns of fiber length in Acacia melanoxylon. Sahri et al. (1993) found the same axial variation in Acacia mangium with a fiber length decrease with height $(1.026 \mathrm{~mm}$ to 0.849 $\mathrm{mm}$ ). Eucalyptus globulus shows the same axial variation of wood fiber length.

The axial variation of bark fiber length observed in Acacia melanoxylon was characterised by a decrease towards the top of the tree (Figure 5) from an average of $1.51 \mathrm{~mm}$ and $1.42 \mathrm{~mm}$ to $1.34 \mathrm{~mm}$ at $5 \%, 35 \%$ and $65 \%$ of total tree height respectively. The maximal mean value was determined at $5 \%$ of total tree height level in Ovar $(1.78 \mathrm{~mm})$ and the minimum in Viseu $(1.26 \mathrm{~mm})$ at $65 \%$ height level. This is a pattern also described by Iqbal and Ghouse (1983) for Acacia nilotica with a variation of 1.12 $\mathrm{mm}$ in the base, $1.16 \mathrm{~mm}$ in the middle and $0.986 \mathrm{~mm}$ in the top of the tree.

The axial variation of Acacia melanoxylon wood and bark fibers showed a similar pattern, suggesting a similar cell differentiation mechanism in phloem and xylem. In Eucalyptus globulus, on the contrary, an inverse trend of fiber length variation was reported for wood and bark, with longer phloem fibers occurring at the top of the stem (JORGE et al., 2000; QUILHÓ et al., 2000).

\subsection{Fiber wall thickness}

Fiber wall thickness for wood and bark varied between 3.45-3.89 $\mu \mathrm{m}$ and 5.01-5.40 $\mu \mathrm{m}$, respectively (Table 3). For wood wall thickness, there was a significant site differences $(\mathrm{P}<0.05)$ between Ovar and Viseu.

Table 3 - Wood and bark fiber wall thickness $(\mu \mathrm{m})$ for Acacia melanoxylon in four sites. Mean and standard deviation of five trees per site.

Tabela 3 - Espessura da parede das fibras da madeira e casca ( $\mu \mathrm{m})$ da Acacia melanoxylon nos quatro locais. Média e desvio padrão das cinco árvores por local.

\begin{tabular}{lcccc}
\hline Site & Caminha & Ponte de Lima & Ovar & Viseu \\
\hline Wood & $3.77 \pm 0.20$ & $3.63 \pm 0.22$ & $3.45 \pm 0.30$ & $3.89 \pm 0.17$ \\
Bark & $5.01 \pm 0.25$ & $5.12 \pm 0.14$ & $5.40 \pm 0.11$ & $5.36 \pm 0.40$ \\
\hline
\end{tabular}

The fiber wall thickness of Acacia melanoxylon wood is larger than the results obtained for Eucalyptus globulus: between 1.8 to $2.3 \mu \mathrm{m}$ (JORGE, 1994), 1.79 $\mu \mathrm{m}$ to $3.06 \mu \mathrm{m}$ (MOURA, 1999), $3.52 \mu \mathrm{m}$ and $3.27 \mu \mathrm{m}$ (ONOFRE, 1999).

For Acacia mangium, Sahri et al. (1993) in wood referred that fiber wall is relatively thin and varies little in thickness (3.1 - $3.5 \mu \mathrm{m}$ and $4.1-4.5 \mu \mathrm{m}$ for 4- and 8-year-old trees respectively), and Richter and Dallwitz (2000) reported very thin to medium wall thickness. The average bark fiber wall thickness fits into the values reported for Acacia bilimekii $(6 \mu \mathrm{m})$ or Acacia cochliacantha $(5 \mu \mathrm{m})$ (QUINTANAR ISAIAS et al., 2005).

In Acacia melanoxylon bark, the fibers had thinner walls than in the bark of Eucalyptus globulus where fiber wall thickness varied between 5-6 $\mu \mathrm{m}$ (QUILHÓ, 1998) and 6-7 $\mu \mathrm{m}$ (QUILHÓ et al., 2000).

\subsubsection{Radial variation of wood fiber wall thickness}

In average, fiber wall thickness in Acacia melanoxylon increased from pith to bark, with some fluctuations (Figure 6), from an average $3.55 \mu \mathrm{m}$ near the pith, to $3.74 \mu \mathrm{m}$ at the middle position and to $3.80 \mu \mathrm{m}$ at the periphery ( $90 \%$ of the distance from pith). The minimal mean value was near the pith in Ovar $(3.32 \mu \mathrm{m})$, and the maximum $(3.94 \mu \mathrm{m})$ in Viseu. Average fiber wall thickness increased more rapidly between pith and middle positions than between middle and periphery positions $(0.19 \mu \mathrm{m}$ and $0.06 \mu \mathrm{m}$ respectively).

Cerne, Lavras, v. 17, n. 1, p. 61-68, jan./mar. 2011 


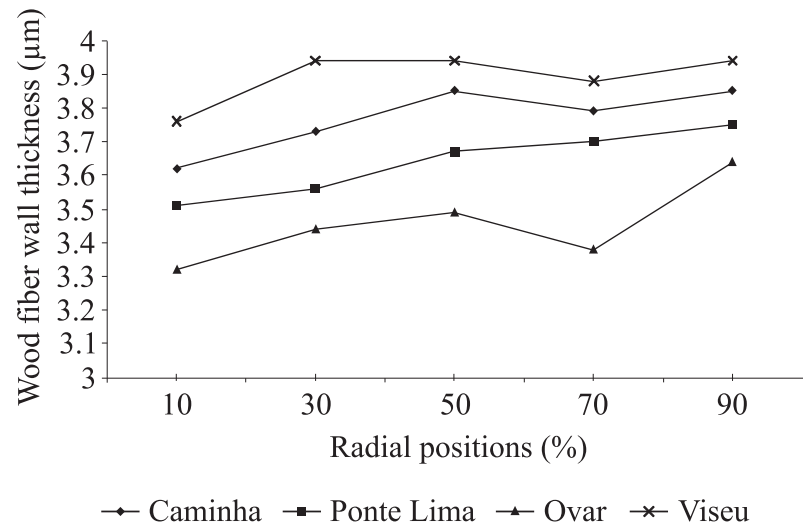

Figure 6 - Radial variation of wood fiber wall thickness of Acacia melanoxylon in four sites.

Figura 6 - Variação radial da espessura de parede das fibras da madeira da Acacia melanoxylon nos quatro locais.

Sahri et al. (1993) in 4 and 8-year-old samples of Acacia mangium observed that the fiber wall is relatively thin and varies little in thickness, between $3.1 \mu \mathrm{m}$ and $3.5 \mu \mathrm{m}$ for 4-year old trees and $4.1 \mu \mathrm{m}$ to $4.5 \mu \mathrm{m}$ for 8 year old trees and Salang e Fujii (2000) reported a slight increase from the pith to the sapwood. Quintanar Isaias et al. (2005) reported in Acacia bilimekii the value of $5 \mu \mathrm{m}$ in the centre and in the periphery and in Acacia cochliacantha an increase from 5 to $7 \mu \mathrm{m}$ from pith to bark.

For Eucalyptus globulus, Jorge (1994) registered also slight increases in wall thickness from pith to bark from $1.8 \mu \mathrm{m}$ to $2.5 \mu \mathrm{m}$ and Onofre (1999) found no radial pattern of wood wall thickness.

\subsubsection{Axial variation of wood and bark fiber wall thickness}

Figures 7 and 8 show the axial variation of wood and bark fiber wall thickness of Acacia melanoxylon in four sites, respectively.

In wood fiber wall thickness had no specific pattern for axial variation (Figure 7). Fiber wall thickness was higher in Viseu and Caminha than in Ponte de Lima and Ovar.

The maximal mean value of fiber cell wall was determined at $5 \%$ of total tree height level in Viseu (3.97 $\mu \mathrm{m})$ and the minimum in Ovar $(3.44 \mu \mathrm{m})$ at the same height level.

For Eucalyptus globulus, the fiber wall thickness increases from the base to $55 \%$ tree height and decreases to the top from $1.97 \mu \mathrm{m}$, to $2.1 \mu \mathrm{m}$ and $2.07 \mu \mathrm{m}$, respectively (JORGE, 1994).

Cerne, Lavras, v. 17, n. 1, p. 61-68, jan./mar. 2011

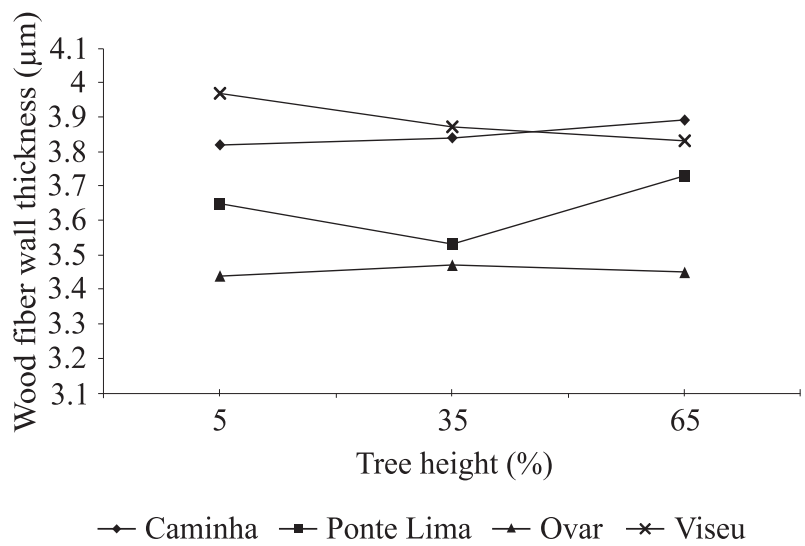

Figure 7-Axial variation of wood fiber wall thickness of Acacia melanoxylon in four sites.

Figura 7 - Variação axial da espessura de parede das fibras da madeira da Acacia melanoxylon nos quatro locais.

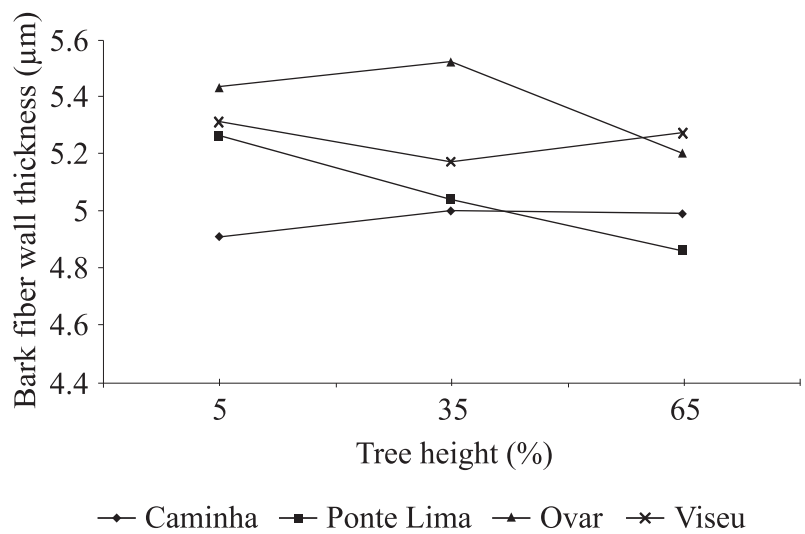

Figure 8 - Axial variation of bark fiber wall thickness of Acacia melanoxylon in four sites.

Figura 8 - Variação axial da espessura de parede das fibras da casca da Acacia melanoxylon nos quatro locais.

In bark, fiber wall thickness had also no specific pattern for axial variation at $5 \%, 35 \%$ and $65 \%$ of total tree height (Figure 8). Bark fiber wall thickness values were lower in Caminha (Figure 8) and the maximal mean value of fiber cell wall was determined at $35 \%$ of total tree height in Ovar $(5.52 \mu \mathrm{m})$ and the minimum in Ponte de Lima $(3.44 \mu \mathrm{m})$ at $65 \%$ height level.

For Eucalyptus globulus, the fiber wall thickness decreases from the base to the top with $7.3 \mu \mathrm{m}, 6.4 \mu \mathrm{m}$, $6.1 \mu \mathrm{m}, 5.5 \mu \mathrm{m}, 5.4 \mu \mathrm{m}$ at $5 \%, 15 \%, 35 \%, 55 \%$ and $75 \%$ of tree height (QUILHÓ et al., 2000). 


\section{CONCLUSIONS}

In the wood of Acacia melanoxylon, fiber length and wall thickness increased radially from pith to bark. Axially the wood fiber length decreased from bottom to the top of the tree and wall thickness had no specific variation pattern.

In the bark of Acacia melanoxylon, fiber length decreased from bottom to the top of the tree and bark wall thickness had no specific variation pattern.

Significant site differences were found only in relation to wood fiber cell wall thickness and bark fiber length.

Fibers of Acacia melanoxylon were similar to those of Eucalyptus globulus in relation to length in wood and bark but wood fibers were thinner and bark fibers thicker.

\section{ACKNOWLEDGMENTS}

We thank POCTI/42594/AGR/2001 for financial support and Fernanda Bessa and Marco Cosme for fiber measurements.

\section{REFERENCES}

CARVALHO, A. Madeira de Eucalipto (Eucalyptus globulus Labill): estudos, ensaios e observações. Lisboa: D.G.S.F.A., 1962.160 p.

GHOUSE, A. K. M.; IQBAL, M. Intrusive growth in the secondary phloem of Acacia and Prosopis. New Botanist, New Delli, v. 6, n. 3, p. 91-96, 1979.

GHOUSE, A. K. M.; IQBAL, M. Trends of size variation in phloem fibers and sieve-tube cells within the bark of some arid-zone trees. Flora, n. 166, p. 517-521, 1977.

GIL, C.; AMARAL, M. E.; TAVARES, M.; SIMÕES, R. Estudo do potencial papeleiro da Acacia spp. In: ENCONTRO DE INVASORAS LENHOSAS, 1., 1999, Gerês. Anais... Gerês: S.P.C.F., 1999. p. 171-178.

HARRIS, S. Tropical ecosystems. In: BURLEY, J.; EVENS, J.; YOUNGQUIST, J. A. (Eds.). Encyclopedia of forest sciences. New York: Elsevier, 2004. v. 4, p. 1668-1674.

HILLIS, W. Properties of eucalypt woods of importance to the pulp and paper industry. Appita, Victoria, v. 26, n. 2, p. 113-122, 1972.
HONJO, K.; FURUKAWA, I.; SAHRI, M. H. Radial variation of fiber length increment in Acacia mangium. IAWA Journal, Leiden, v. 26, n. 3, p. 339-352, 2005.

IGARTÚA, D. V.; MONTEOLIVA, S. E.; MONTERUBBIANESI, M. G.; VILLEGAS, M. S. Calidad del leño en Eucalyptus globulus ssp. globulus: II., variaciones en la densidade básica y la longitud de fibras en Lobería, Provincia de Buenos Aires, Argentina. Revista de la Facultad de Agronomia, La Plata, v. 105, p. 29-39, 2002.

ILVESSALO-PFAFFLI, M. S. Fiber atlas: identification of paper making fibers. Berlin: Springer Series in Wood Science, 1995. $400 \mathrm{p}$.

IQBAL, K.; GHOUSE, A. K. M. An analytical study on cell size variation in some arid zone trees of India: Acacia nilotica and Prosopis spicigera. IAWA Bulletin, Leiden, v. 4, n. 1, p. 46-52, 1983.

JENNINGS, S. M.; WILKINSON, G. R.; UNWIM, G. L. Response of blackwood (Acacia melanoxylon) regeneration to silvicultural removal of competition in regrowth eucalypt forests of north-west Tasmania, Australia. Forest Ecology Management, Amsterdam, v. 177, n. 1/3, p. 75-83, 2003.

JORGE, F.; QUILHÓ, T.; PEREIRA, H. Variability of fiber length in wood and bark in Eucalyptus globulus. IAWA Journal, Leiden, v. 21, n. 1, p. 41-48, 2000.

JORGE, M. F. C. T. F. Variabilidade anatômica, física e química da madeira de Eucalyptus globulus Labill. 1994. 213 p. Tese (Doutorado em Ciências Florestais) - Universidade Técnica de Lisboa, Instituto Superior de Agronomia, Lisboa, 1994.

KIM, N. T.; OCHIISHI, M.; MATSUMURA, J. Variation in wood properties of six natural acacia hybrid clones in northern Vietnam. Journal of Wood Science, Amsterdam, v. 54, n. 6, p. 436-442, 2008.

LIM, S. C.; GAN, K. S. Some physical properties and anatomical features of 14-year-old Acacia mangium. Journal of Tropical Forest Products, v. 6, p. 206-213, 2000.

LOGAN, A. F.; BALODIS, V. Pulping and papermaking characteristics of plantation grown Acacia mangium frm Sabah. Malays. Forest, v. 45, p. 217-236, 1982.

Cerne, Lavras, v. 17, n. 1, p. 61-68, jan./mar. 2011 
MIRANDA, I.; PEREIRA, H. Variation of pulpwood quality with provenances and site in Eucalyptus globulus. Annals of Forest Science, v. 59, p. 283-291, 2002.

MOURA, M. J. C. de. Caracterização morfológica da madeira de Eucalyptus globulus: estudos de variabilidade numa árvore. 1999. 148 p. Dissertação (Mestrado em Processos Químicos) - Universidade de Coimbra, Coimbra, 1999.

ONA, T.; SONODA, T.; ITO, K.; SHIBATA, M.; TAMAI, Y.; KOJIMA, Y.; OHSHIMA, J.; YOKOTA, S.; YOSHIZAWA, N. Investigation of relationships between cell and pulp properties in Eucalyptus by examination of within-tree property variations. Wood Science and Technology, Amsterdam, v. 35, p. 229-243, 2001.

ONOFRE, R. A. G. Variabilidade anatómica da madeira da Eucalyptus globulus Labill: proveniente de povoamentos da Soporcel, em condições de crescimento contrastantes. 1999. 74 p. Dissertação (Mestrado em Engenharia Florestal) Universidade Técnica de Lisboa, Lisboa, 1999.

PEDIEU, R.; RIEDEL, B.; PICHETTE, A. Properties of mixed particleboards based on white birch (Betula papyrifera) inner bark particles and reinforced with wood fibers.

European Journal of Wood Products, Cambridge, v. 67, n. 1, p. 95-101, 2009.

QUILHÓ, T. Variabilidade da estrutura anatómica da casca de Eucalyptus globulus Labill. 1998. 224 p. Tese (Doutorado em Engenharia Florestal) - Universidade Técnica de Lisboa, Instituto Superior de Agronomia, Lisboa, 1998.

QUILHÓ, T.; PEREIRA, H.; RICHTER, H. G. Within-tree variation in phloem cell dimensions and proportions in Eucalyptus globulus. IAWA Journal, Leiden, v. 21, n. 1, p. 31-40, 2000.
QUINTANAR ISAIAS, A.; NUNEZ, V. M.; ARENAS, F. S.; PEREZ, O. C.; TORRE-BLANCO, A. Secondary stem anatomy and uses of four drought-deciduous species of a tropical dry forest in México. Revista de Biologia Tropical, Goiânia, v. 53, n. 1/2, p. 29-48, 2005.

RICHTER, H. G.; DALLWITZ, M. J. Commercial timbers: descriptions, illustrations, identification and information retrieval. Version 4. 2000. Available in: $<$ htpp://biodiversity. uno.edu/delta/>. Access in: 10 abr. 2008.

SAHRI, M. H.; IBRAHIM, F. H.; SHUKOR, N. A. Anatomy of Acacia mangium grown in Malaysia. IAWA Journal, Leiden, v. 4, n. 3, p. 245-251, 1993.

SALANG, A. T.; FUJII, T. Physical and anatomical characteristics of Acacia mangium Willd planted in Sarawak, Malaysia. In: IUFRO WORLD CONGRESS, 21., 2000, Kuala Lumpur. Proceedings... Kuala Lumpur: IUFRO, 2000.

TAVARES, F.; MONTEIRO, C.; MONTEIRO, J.; PEREIRA, $\mathrm{H}$. Radial variation of fiber length and vessel characteristics of Eucalyptus globulus Labill. at the end of the second rotation. In: BORRALHO, N. M. G.; PEREIRA, J. S.; MARQUES, C.; COUTINHO, J.; MADEIRA, M. (Eds.). Eucalypts in a changing world. Aveiro: Instituto de Investigação da Floresta e Papel, 2004. p. 707-708.

TOMAZELLO FILHO, M. Variação radial da densidade básica e da estrutura anatómica da madeira do Eucalyptus globulus, E. pellita e E. acmenioides. Instituto de Pesquisa e Estudos Florestais, Piracicaba, v. 36, p. 35-42, 1987.

WU, S. C.; WANG, Y. C. The wood properties of acacia mangium and acacia auriculiformes. Q. J. Exp. Forest. NTU 2: 59-88. IAWA Journal, Leiden, v. 26, n. 3, p. 339-352, 2005 . 